\title{
Review
}

\section{Democracy and goodness: A historicist political theory}

\author{
John R.Wallach \\ Cambridge: Cambridge University Press, 2018, \\ xii + 310 pp., ISBN: 978-1-108-43556-7
}

Contemporary Political Theory (2020) 19, S235-S238. https://doi.org/10.1057/s41296019-00353-9; published online 1 October 2019

Is contemporary political theory able to diagnose the present crisis of democracy? Does it effectively valorize its knowledge to address contemporary political problems? Are its approaches and reflections sufficiently precise to grasp the intricacies of our political problems? No, is the answer that John R. Wallach gives in Democracy and Goodness: A Historicist Political Theory. Contemporary political theory does not take the subtle dynamics between power and ethics in concrete political life into account. Instead, it pays to much attention to abstract normative principles, political ideals, various modalities of justification, and rational reconstructions. However, if contemporary political theory considers democracy to be a good worth defending, it should aim at understanding democracy as an imperfect work in progress, always in medias res, and as a conflictual political order. To pursue that aim, one needs to study democracy and the subtle dynamics of power and ethics in concrete political life from a historicist perspective-John R. Wallach claims. What does that entail?

Democracy and Goodness is a thematic history of the European and American canons of political thought from the ancient Greece to the contemporary political debates in Europe and primarily the US. There is a clear thematic focus on the relationship between democracy as a form of political power and goodness as a kind of political ethics, which have different and various expressions depending on temporal and spatial contexts. Within this framework, the normative question is how to constitute political practices that make the exercise of power by the people possible, based on the premise that it is a good for the citizenry. However, the promotion of demotic agency does not follow a single formula. One has to understand it in its historical context and get sufficiently detailed insights into its use for addressing practical political problems and pave the way for political action. With this in mind, what does a historicist political theory mean?

A historicist perspective links the past, present, and future. It provides a critical tool for understanding the relationship between democracy and goodness by

(c) 2019 Springer Nature Limited. 1470-8914 Contemporary Political Theory Vol. 19, S4, S235-S238 
focusing, on the one hand, on historicizing democracy as an activity and, on the other, on the various legitimizing conceptions of goodness at different historical periods. The point of historicizing democracy is to pay attention to public exercises of power, rather than to democratic, constitutional, and institutional characteristics only. Also, with a focus on political actions, one gets to understand the ethical character and dispositions of political agents. Furthermore, historicizing democracy enables us to identify practical problems and the role played by political agents in problem solving. However, in order to judge and assess the democratic role played by political agents, one has to be aware of various standards of goodness articulated in concrete historical times and spaces.

These various legitimizing conceptions of goodness embedded in democratic life constitute the thematic focal points that structure the historical narrative told in Democracy and Goodness: conceptions of virtue in Ancient Greece, representation in 17th and 18th Century, civil rightness in 19th and early 20th Century, legitimacy in twentieth Century and human rights since the Second World War. In each historical period, the various conceptions of goodness have played an aspirational role and constituted horizons for democratic actions. Wallach pays special attention to demotic agency as a focal point for generating democratic ethics, contesting the concrete historical conceptions of goodness and for constituting horizons for political actions in the past, present and future. From his point of view, the question is whether deliberate thoughts at the conceptual level constitute practice and, if not, what the deliberate thoughts might involve in practice. In technical terms, there is a tension between logos and ergon. Against this background tension, Wallach's historicist perspective differs from other so-called historicist perspectives that pay insufficient attention to democratic practices by the citizenry. To better tease out the main argument advanced here, let us look at two chapters on the historical contestation of conceptions of goodness.

In the first historical chapter, Wallach focuses on political virtues as conceived in ancient Greece and Athenian democracy. He aims to tell a different story from the one we are used to in the history of political thought. That story has set in stone an opposition between democracy (demokratia) and virtue (arête). However, according to the overall argument in this book, there is a complementarity between democracy and virtue, understood as a dynamic relationship between power and ethics. In the Athenian democracy, virtue referred to the character of the citizenry, cultivated as a political collective through political actions. It was not only the few best men of an aristocracy who had the potential to become virtuous; the many involved in the Athenian democratic practices geared toward the common good also shared in this potential. Thus, political virtues were critical standards for assessing the exercise of power and a reservoir of sources for reflection and reactions against eventual demagogues and despotism. Plato's and Aristotle's skepticism toward democracy as a tyranny of the many is eschewed here. The 
critical standard in the Athenian democracy was the virtues of the many, rather than that of the few, claims Wallach.

In the fifth historical chapter, Wallach tells the story of human rights as a conception of goodness, which started with the Second World War. Given the fact that the founding documents and declarations mention human rights and democracy in the same sentences, the crucial question is how human rights relate to democracy as a good. How do human rights enable the promotion of democracy at various political levels from local to global? The problem in contemporary human rights discourse is the attention we pay to human rights as a negative standard, when political regimes violate them, rather than as a positive and realistic political ideal. The question is how human rights can constitute goods that demotic agents aim at via their democratic means and procedures. An aspirational understanding of human rights makes them a good and embeds them in concrete democratic practices - rather than sanctify them as abstract political ideals. In other words, human rights as logos are realized by the practices (ergon) and political actions of the democratic citizenry. The democratic citizenry integrates and transforms itself by promoting human rights in concrete political action.

The five chapters of John R. Wallach's thematic history of various legitimizing conceptions of goodness show a sincere engagement in the democratic practices of active citizens at different historical times in European and American politics. We get deep and detailed historical insights into the inherent tensions, dangers and dead ends of democratic life, potentially relevant for the authoritarian tendencies in contemporary democracies. These are insights gained by taking the temporal and spatial context seriously. However, what does context mean for addressing our political problems in democratic life?

Wallach wrote the book in an American context and I read it in a European context. Does that matter? What does this involve for the questions he raised, for his understandings of the relationship between power and ethics, and for his focus on active citizenship as a parameter for ethical and critical reflections of democratic life? How does one know whether the political actions of the citizenry are genuine and motivated by democratic conviction rather than orchestrated by an authoritarian leader? How does one know whether an active citizenship constitutes itself and contributes to the goodness of democracy? Let me give an example that resonates with the idea of human rights centered political practices as an aspirational democratic good. Thirty years ago, people assembled in the Saint Nikolaj Church and went into the streets of Leipzig in the then German Democratic Republic claiming their human, political and civil rights under the slogan, "We are the people." Last year, a group of people associated with the party Alternative for Germany and the neo-Nazis went into the streets of Chemnitz, the former Karl Marx city, claiming that they are the people, not in terms of human rights, but in terms of their German nationality, defined exclusive of immigrants and refugees. Was that an aspirational claim of democratic self-determination, or was it a

(c) 2019 Springer Nature Limited. 1470-8914 Contemporary Political Theory Vol. 19, S4, S235-S238 S237 
violation of the idea of human rights? The example illustrates the actual complexity and problematic nature of taking the political actions of the citizenry as a measure of the goodness of democracy.

Democracy and Goodness does not eliminate such a doubt about democracy as a good in the actual crisis of democracy, whether American or European. However, it directs our attention to the importance of getting deeper and more detailed historical insights in order to understand and engage with current democratic problems. Thus, it gives a hopeful horizon for democratic action without guarantees. The proof is in getting involved in concrete political circumstances and the concrete practices of contesting goodness.

Publisher's Note Springer Nature remains neutral with regard to jurisdictional claims in published maps and institutional affiliations.

Anders Berg-Sørensen

University of Copenhagen, 1165 Copenhagen, Denmark abs@ifs.ku.dk 